snow has been falling from the lowered sky, a snow colder than snow.

Translated by the author with John Batki

ANADAD ELDON / ISRAEL

\title{
When You Gave Light to Israel
}

When you gave light to the sun and sun to the morning,

I went to you, your only child.

The trees screened the flowing water, on their branches you hung white birds;

and on me, pupils, dark as my shoes.

Bare-footed, the trees are rooted upright, making God's years green.

Give my legs back those years my father spent by the swamps that ran here from hillock to hillock-

whistling, hanging his clothes out to dry.

He built a channel for tears; for pain shelter in my eyes.

When I see white birds, resting on the tops of trees, it seems

God or his angels are about.

Translated by Bat-Sheva Sheriff and Jon Silkin 